\title{
The Use of Colour Metallography and EDS for Identification of Chemical Heterogeneity of Selected Aluminium Alloys Copper and Zinc Alloyed
}

\author{
Viktorie Weiss ${ }^{1}$, Jaroslava Svobodová ${ }^{2}$ \\ ${ }^{1}$ The Institute of Technology and Business in České Budějovice, Okružní 517/10, 37001 České Budějovice. Czech Re- \\ public.E-mail: 19638@mail.vstecb.cz \\ ${ }^{2}$ Faculty of Production Technology and Management, J. E. Purkyně University in Ústi nad Labem, Pasteurova 3334/7, \\ 40001 Usti nad Labem. Czech Republic. E-mail: svobodova@fvtm.ujep.cz
}

\begin{abstract}
Aluminium alloys with higher content of alloying elements are very susceptible to the emergence of crystal segregation that significantly affects the mechanical, physical and chemical properties of these alloys. Crystal segregation is called chemical heterogeneity in microscale and is formed during crystallization. Crystallization of alloys does not occur at a particular temperature, as is the case of pure metals, but in a certain temperature interval. During cooling of the melt occurs to formation of different regions within the dendritic cell that differs in chemical composition. Generally is crystal segregation defined as chemical heterogeneity formed during alloy crystallization that is enriched or deprived of alloying elements and impurities that segregate unevenly across the surface of the dendrites. In the central area of the dendritic cells is alloy deprived of alloying elements, while the outer parts of dendritic cells and in space between dendrites is the concentration of alloying elements richer. This concentration has a hyperbolic course, when the central region of dendritic cells has the lowest concentration of the alloying elements and the outer part of dendrite boughs and interdendritic space have the maximum. Distribution of individual elements has a recurring character and can be described by sine function. The distance between two main axes of dendritic cells is affected by the temperature interval between the liquidus and solidus for the given alloy, the cooling rate of the melt and temperature gradient during solidification. Formation of the crystal segregation in aluminium alloys rich in alloying element and additives cannot be prevented, it is possible only influence its scope and with the right choice of heat treatment parameters can be suppressed. To suppress the crystal segregation the castings are subjected to heat treatment which is called homogenization annealing. It is the diffusion process in which there occurs to a balancing of chemical composition of alloy and the uniformity of its structure.
\end{abstract}

Keywords: crystal segregation, colour metallography, intermetallic phase, eutectic, colour etching, AlCu4MgMn, $\mathrm{AlZn} 5.5 \mathrm{MgCu}$, EDS

\section{References}

[1] MICHNA, Š., LUKÁČ, I. et al. (2007). Aluminium materials and technologies from A to Z, Printed by Adin, s.r.o., Prešov. ISBN 978-80-8244-18-8.

[2] LUKÁC̆, I., MICHNA, Š. (1999). Atlas struktur a vad u hliníku a jeho slitin, Deltaprint, Děčín, ISBN 80-2384611-6.

[3] MICHNA, Š., NOVÁ, I. (2008). Technologie a zpracování kovových materiálů, Adin, s.r.o., Prešo, ISBN 978-8089244-38-6.

[4] VAJSOVÁ, V. (2011). Optimization of homogenizing annealing for Al-Zn5.5-Mg2.5-Cu1.5 alloy, Metallurgist, Volume 54, Issue 9, ISSN 0026 - 0894.

[5] VAJSOVÁ, V., MICHNA, Š. (2010). Optimization of AlZn5.5Mg2.5Cu1.5, Alloy Homogenizing Annealing, Metallofizika i noveishie tekhnologii, Volume 32, No. 7, ISSN 1024 - 1809.

[6] WEISS, V., STŘIHAVKOVÁ, E. (2012). Influence of the homogenization annealing on microstructure and mechanical properties of AlZn5,5Mg2,5Cu1,5 alloy, Manufacturing Technology, Vol. 12, No, 13, ISSN 1213 -2489.

[7] STŘIHAVKOVA, E., WEISS, V. (2012) The Identification of the struktures new type Al-Si-Mg Ca alloys with different Ca kontent using of the color metallography, Manufacturing Technology, Vol. 12, No, 13, ISSN 1213 2489.

[8] WEISS, V. (2012). Hodnoceni vlivu teploty a doby homogenizačního žíhaní slitiny AlCu4MgMn z hlediska mikrostruktury, obrazové analýzy a metody EDX, Strojírenská technologie, ročník XVII, ISSN 1211 - 4162.

[9] WEISS, V., STŘIHAVKOVÁ, E. (2011). Optimalizace homogenizačního žíhaní slitiny AlCu4MgMn, Strojírenská technologie, ročník XVI, ISSN 1211 - 4162.

[10]WEISS, V. (2012). Vliv slévárenských forem na kvalitu povrchu a strukturu slitiny AlZn5,5Mg2,5Cu1,5, Strojirenská technologie, ročník XVII, č. 1 a 2, 2012, ISSN 1211 - 4162.

[11]WEISS, V. (2012). Hodnoceni vlivu teploty a doby homogenizačního žíhaní slitiny AlCu4MgMn z hlediska mikrostruktury, obrazové analýzy a metody EDX, Strojírenská technologie, ročník XVII, ISSN 1211 - 4162. 